\title{
Correlation between CD4 cell counts with mucocutaneous manifestations: study of HIV patients in Dr. Sardjito General Hospital, Yogyakarta
}

\author{
Satiti Retno Pudjiati, Nadia Akita Dewi*, Sekar Sari Arum Palupi \\ Department of Dermatology and Venereology, Faculty of Medicine, Universitas Gadjah \\ Mada/Dr. Sardjito General Hospital, Yogyakarta
}

DOI: http://dx.doi.org/10.19106/JMedSci005001201805

\begin{abstract}
Mucocutaneous disorders often seen in HIV patients with varying morbidity. The HIV progression is characterized by the declining of CD4 cell counts and emergence of mucocutaneous manifestations. The aim of the study was to evaluate the relationship between CD4 cell counts with mucocutaneous manifestations in HIV patients. This was a cross-sectional study based on medical records at Dr. Sardjito General Hospital during the period January 2011-December 2015. Data of patient's age, sex, risk factors of transmission, most mucocutaneous manifestations and CD4 cell count were gathered. The correlation between CD4 cell counts with muscocutaneous manifestations were analyzed using chi-square test. A total 928 patients were involved in the study. More than half of the patients were male $(65.4 \%)$ and mostly, the patients aged $20-29$ years $(38.69 \%)$. The main risk factors for HIV transmission were unsafe sex (75\%). The highest CD4 cell counts was 1094 cells $/ \mathrm{mm}^{3}$ and the lowest was $1 \mathrm{cell} / \mathrm{mm}^{3}$. We found 306 cases of mucocutaneous manifestations. The most mucocutaneous manifestations was a fungal infection $(40.4 \%)$ with the highest infection type was oral candidiasis $(33.8 \%)$; then noninfection (28\%) with the highest type was drug eruption(35.9\%); and tumors(0.5\%) that was only Kaposi sarcoma cases. We also found sexually transmitted infections (STIs) $(18.85 \%)$ with the highest cases was condyloma acuminata $(49.3 \%)$. Statistical analysis showed a significantly relationship between CD4 cell counts with a fungal infection ( $p$ $<0.0001 ; \mathrm{OR}=3.8 ; 95 \% \mathrm{Cl}: 2.29-6.30)$, viral infection $(\mathrm{p}=0.0031 ; \mathrm{OR}=0.4 ; 95 \%$ $\mathrm{Cl}: 0.24-0.74)$ and parasitic infection $(\mathrm{p}=0.043 ; \mathrm{OR}=0.2 ; 95 \% \mathrm{Cl}: 0.06-0.61)$. In conclusion, alteration in CD4 cell counts affects opportunistic infections occurence in HIV patients. Lower CD4 cell counts $\left(<200\right.$ cells $\left./ \mathrm{mm}^{3}\right)$ increases the risk of fungal infection as much as 3.8 times. Higher CD4 cell counts $\left(>200\right.$ cells $/ \mathrm{mm}^{3}$ ) increases the risk of viral infection by about 2.5 times and parasitic infections as much as 5 times.
\end{abstract}

\section{ABSTRAK}

Kelainan mukokutan sering dialami pasien HIV dengan morbiditas yang bervariasi. Progresitas HIV ditandai dengan penurunan angka CD4 dan munculnya manifestasi mukokutan. Penelitian ini bertujuan untuk mengkaji hubungan antara angka CD4 dengan manifestasi mukokutan pada pasien HIV. Penelitian dengan rancangan potong lintang ini dilakukan dengan mengambil data dari rekam medis di RSUP Dr. Sardjito, Yogyakarta selama periode Januari 2011-Desember 2015. Data umur pasien, jenis kelamin, faktor risiko penularan, manifestasi mukokutan paling sering terjadi dan angka CD4 dikumpulkan.

\footnotetext{
*coresponding author: akita.nadia@gmail.com
} 
Hubungan antara angka CD4 dan manifestasi mukokutan dianalisis dengan uji chi square. Total 928 pasien terlibat dalam penelitian. Lebih setengah pasien adalah pria $(65,4 \%)$ dan sebagian besar berumur antara $20-29$ tahun (38,69\%). Faktor risiko utama penularan HIV adalah perilaku seksual tidak sehat (75\%). Angka CD4 tertinggi adalah $1094 \mathrm{sel} / \mathrm{mm}^{3}$ dan terendah adalah $1 \mathrm{sel} / \mathrm{mm}^{3}$. Ditemukan 306 kasus manifestasi mukokutan dengan paling banyak berupa infeksi jamur (40.4\%) sebagian besar disebabkan kandidiasis oral $(33,8 \%)$; selanjutnya bukan Karena infeksi (28\%) sebagian besar disebabkan erupsi obat $(35,9 \%)$ dan tumor $(0,5 \%)$ yaitu Kaposi sarcoma. Infeksi penularan seksual ditemukan sebanyak $18,5 \%$ dengan kasus paling banyak condyloma acuminate $(49,3 \%)$. Hasil analisis statistic menunjukkan hubungan nyata antara angka CD4 dengan infeksi jamur $(\mathrm{p}<0,0001$; OR $=$ $3,8 ; 95 \% \mathrm{Cl}: 2,29-6,30)$, infeksi virus ( $\mathrm{p}=0,0031 ; \mathrm{OR}=0,4 ; 95 \% \mathrm{Cl}: 0,24-0,74)$ dan infeksi parasit $(\mathrm{p}=0,043 ; \mathrm{OR}=0,2 ; 95 \% \mathrm{Cl}: 0,06-0,61)$. Dapat disimpulkan, perubahan angka CD4 menyebabkan terjadinya infeksi oportunitis pasien HIV. Angka CD4 lebih rendah $\left(<200 \mathrm{sel} / \mathrm{mm}^{3}\right)$ meningkatkan risiko infeksi jamur sebesar 3,8 kali. Angka CD4 lebih tinggi $\left(>200 \mathrm{sel} / \mathrm{mm}^{3}\right.$ ) meningkatkan risiko infeksi virus sebesar 2,5 kali dan infeksi parasit sebesar 5 kali.

Keywords: CD4 cell count- mucocutaneous manifestations - HIV - opportunistic infection - fungal infection

\section{INTRODUCTION}

Human immunodeficiency virus (HIV) is still remain a main global health problem. ${ }^{1}$ At the end of 2016, 36.7 million people were living with HIV and one million people died of AIDS-related causes around the world. An estimated 1.8 million people became newly infected with HIV in 2016. The burden of the HIV/AIDS worldwide vary based on countries and regions. Sub-Saharan Africa remains most severely affected, with nearly 1 in every 25 adults (4.2\%) living with HIV or nearly two-thirds of the people living with HIV worldwide. ${ }^{2}$ Indonesia is one country with rapid growing of incidence of HIV/AIDS than other Asian countries. In Indonesia in 2014, about 22.869 new cases have been reported by Ministry of Health and Yogyakarta Special Region ranked $4^{\text {th }}$ from the 33 provinces. ${ }^{3,4}$

Human immunodeficiency virus infection is characterized by a progressive decline of CD4 cell count which associated with impairment of cellular immune system and increasing susceptibility to opportunistic infections. Mucocutaneous manifestations are the common opportunistic infection found in the HIV patients. The mucocutaneous manifestations have been associated with the CD4 cell counts and used in the initial of HIV infection and in determining the clinical stage of the disease..$^{5-8}$ This study aimed to evaluate the relationship between CD4 cell counts and mucocutaneous manifestations in HIV patients in the Dr. Sardjito General Hospital, Yogyakarta.

\section{MATERIALS AND METHODS}

\section{Subjects}

This was an observational study with a cross-sectional design conducted in Department of Dermatology and Venereology, Faculty of Medicine, Universitas Gadjah Mada/Dr. Sardjito General Hospital, Yogyakarta. Data were obtained from medical records of HIV patients during the period January 2011-Desember 2015.

\section{Protocol of study}

The protocol of the study was conducted after ethical approval from the Medical and 
Health Research Ethics Committee, Faculty of Medicine, Universitas Gadjah Mada/ Dr. Sardjito General Hospital was obtained. Data of the HIV patients included age, sex, risk factors of transmission, mucocutaneous manifestations and CD4 cell counts were gathered from the Medical Records Department (MRD), Dr. Sardjito General Hospital, Yogyakarta and evaluated.

\section{Statistical analysis}

Data were presented as mean \pm standard deviation (SD) or percentage. The relationship between CD4 cell counts and mucocutaneous manifestations were analysed using chi-square test or Fisher exact test. A p value $<0.05$ was considered significant.

\section{RESULTS \\ Demography}

As much as 1,241 data of HIV patients were obtained, however only 928 data could be selected and only 313 data could be analysed due to incomplete data. The highest CD4 cell counta was 1094 cells $/ \mathrm{mm}^{3}$ and the lowest was $1 \mathrm{cell} / \mathrm{mm}^{3}$. More than half of the subjects were 607 male (65.4\%) and 321 were female $(34.5 \%)$. The ratio of male:female was about 1.89: 1. The mean of the patients age was $39 \pm 14.2$ years, wit the youngest patients was 5 months and the oldest was 79 years. The highest HIV cases found on the age group $20-29$ years $(38.69 \%)$ (FIGURE 1$)$. The main risk factors for HIV transmission was unsafe sex (75\%) (FIGURE 2).

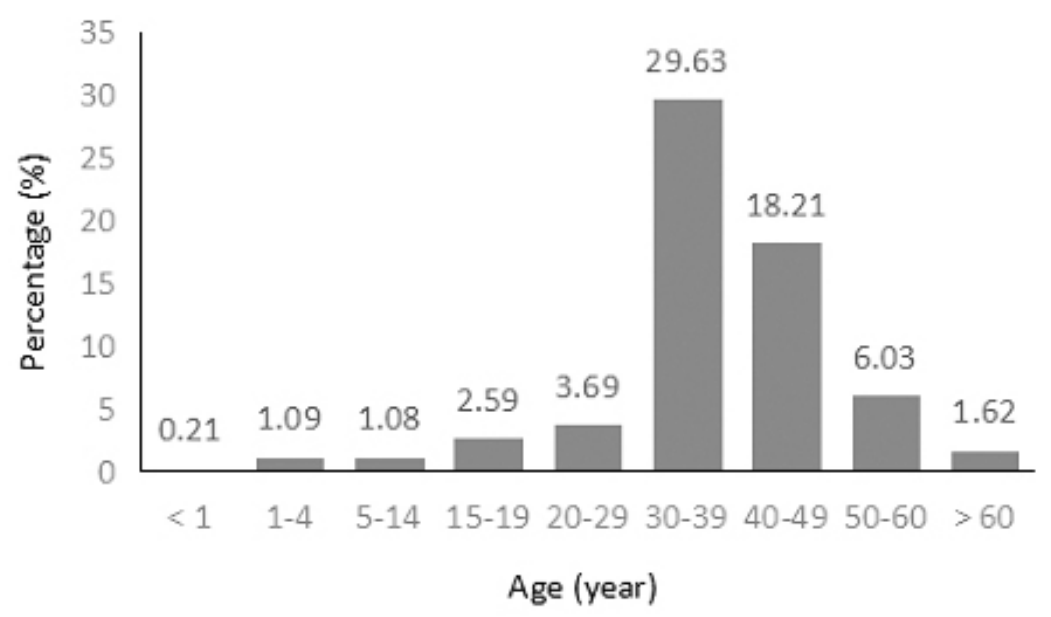

FIGURE 1. Number of HIV patients (\%) according to age range

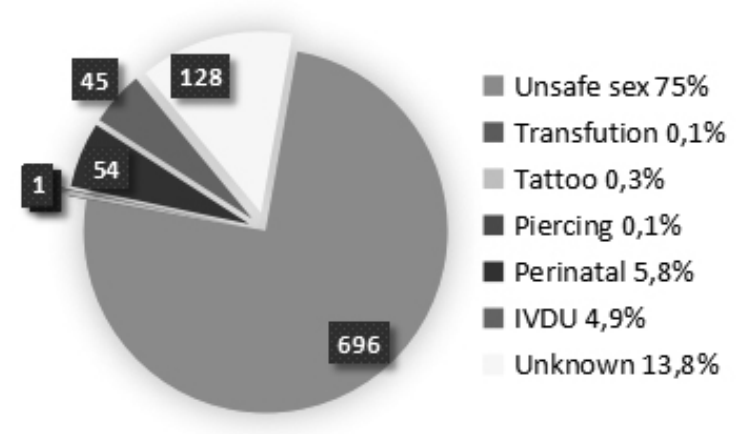

FIGURE 2. Number of HIV patients (n) accordinng to transmission risk factors

\section{Mucocutaneous manifestations in HIV patients}

Of the 205 HIV patients, 366 cases of mucocutaneous manifestations consisting of 261 cases of infection, 103 cases of noninfection and 2 cases of tumor were observed. The most type of infection found in this study was a fungal infection with $38.3 \%$ of them was oral candidiasis. The most cases of noninfection types were drug eruption (35.9\%) 
and we found only Kaposi's Sarcoma for tumor cases $(0.5 \%)$ (FIGURE 3 ).

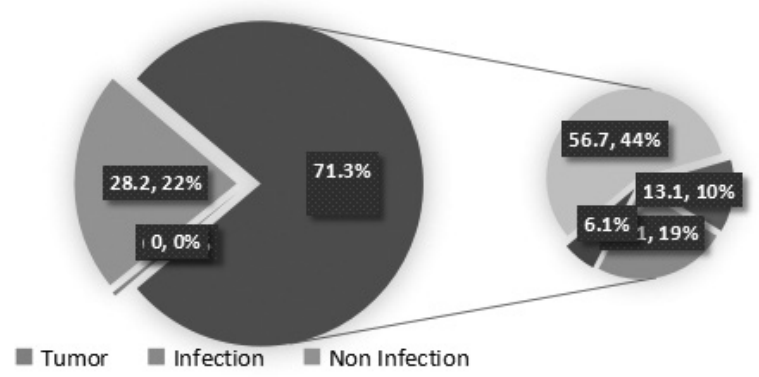

FIGURE 3. Mucocutaneous manifestations in patients with HIV and mucocutaneous manifestations by infection

If we divided the infection by the types, STIs and non-STIs, we found more non-STIs cases (74\%) (FIGURE 4). Meanwhile for STIs cases, the highest type was genital wart cases $(49.3 \%)$ (FIGURE 5)

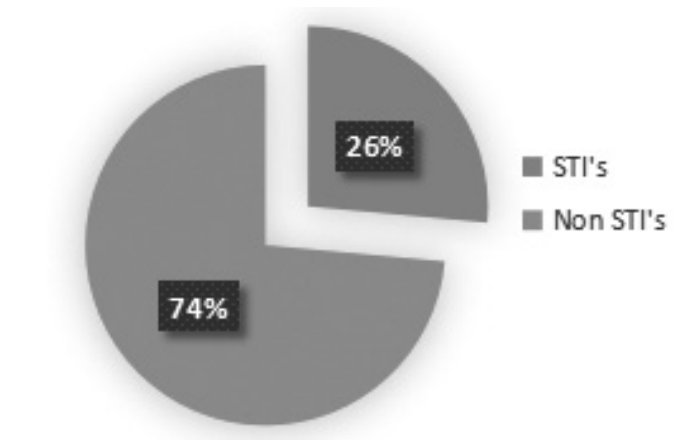

FIGURE 4. Percentage of cases of STIs and non-STIs in patients with HIV

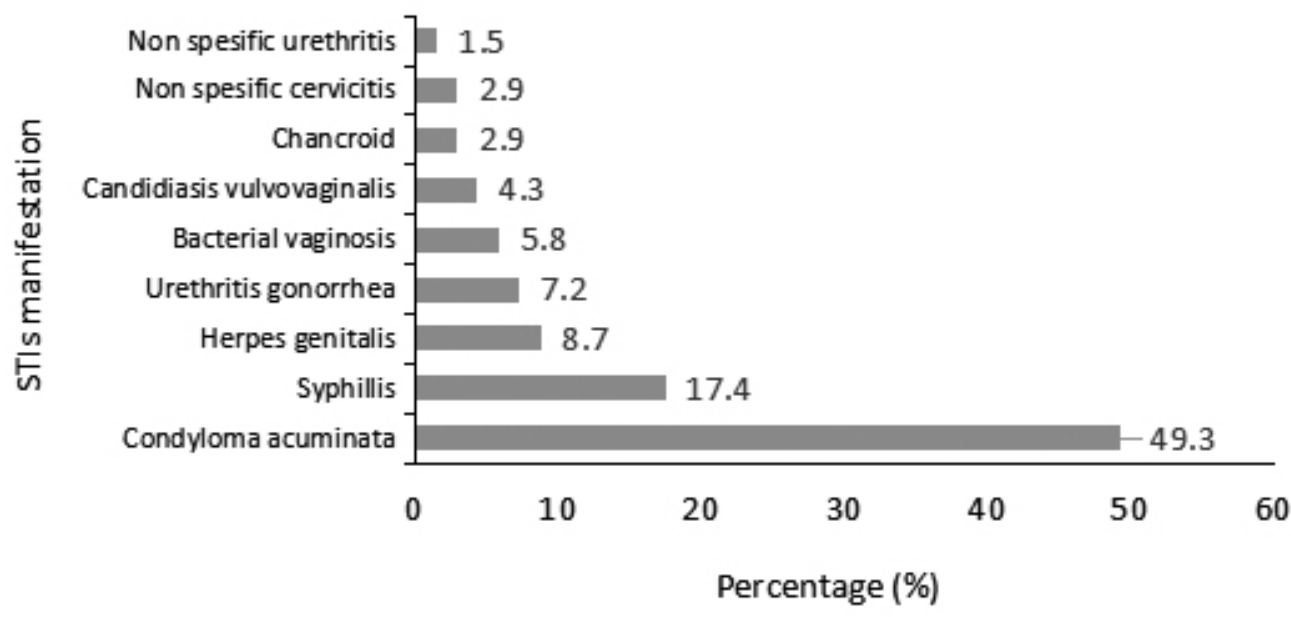

FIGURE 5. Percentage of STIs clinical manifestations in HIV patients

\section{Relationship between CD4 cell counts and mucocutaneous manifestations}

Significantly association between fungal infection $(\mathrm{p}<0.0001$; OR $3.8 ; 95 \%$ CI 2:29 to $6: 30)$, viral infections ( $\mathrm{p}=0.0031$; OR 0.4 ; 95\% CI 0:24 - 0.74) and parasites infection ( $\mathrm{p}=0.043$; OR 0.2 ; 95\% CI 0:06 - 0.61) were observed in this study (TABLE 1). Strong relationships with CD4 cell counts $<200$ cells $/ \mathrm{mm}^{3}$ only found in fungal infections with a risk of 3.8 times compared with CD4 cell counts $\geq 200$ cells $/ \mathrm{mm}^{3}$. In contrast, the number of CD4 cell counts $\geq 200$ cells/ $\mathrm{mm}^{3}$ was associated with increased risk of parasite infection and virus 5 and 2.5 times, respectively. 
TABLE 1. The correlation between CD4 cell count and mucocutaneous manifestation

\begin{tabular}{lccccc}
\hline $\begin{array}{c}\text { Mucocutaneous } \\
\text { manifestation }\end{array}$ & $\begin{array}{c}\text { Total } \\
\mathbf{n = 3 6 6} \mathbf{( \% )}\end{array}$ & $\begin{array}{c}\text { Case with } \\
\mathbf{C D 4}<\mathbf{2 0 0} \\
\mathbf{n = 2 4 6} \mathbf{( \% )}\end{array}$ & $\begin{array}{c}\text { Case with } \\
\mathbf{C D 4} \geq \mathbf{2 0 0} \\
\mathbf{n = 1 2 0} \mathbf{( \% )}\end{array}$ & $\mathbf{p}$ & OR (95\% CI) \\
\hline Fungal infection & 40.4 & 50 & 20.8 & $<0.0001$ & $3.8(2.29-6.37)$ \\
Viral infection & 17.3 & 13 & 25.9 & 0.0031 & $0.4(0.24-0.74)$ \\
Bacterial infection & 9.3 & 7.3 & 13.3 & 0.083 & $0.5(0.25-1.04)$ \\
Parasite infection & 4.4 & 2.0 & 9.2 & 0.0043 & $0.2(0.06-0.61)$ \\
Non infection & 28.2 & 27.3 & 30 & 0.6210 & $0.8(0.53-1.41)$ \\
Tumor & 0.5 & 0.4 & 0.8 & 0.5488 & $0.4(0.03-7.8)$ \\
\hline
\end{tabular}

\section{DISCUSSION}

The majority of HIV patients in this study occurred in the age group 20-29 years old. This is consistent with general age of HIV patient reported by the Ministry of Health, Republic of Indonesia in 2014. ${ }^{3}$ The HIV patients predominantly were males, with a ratio of male to female was 1.89: 1. A prevous study conducted in India by Singh et al. ${ }^{6}$ reported HIV patients also was dominated by male than female with a ratio 1.5: 1 . Based on the AIDS data center of Ministry of Health, since 1987 to 2014, cases of HIV infection had been dominated by males with a ratio of 2: 1 . It can be caused by the rising number of men sex with men (MSM) who practicing unsafe sex and intravenous drug users (IVDU) which is dominated by male. ${ }^{4,9}$

Unsafe sex was the highest risk factor of HIV transmission in this study. Aydin et al. ${ }^{5}$ reported the main risk of HIV transmission among Turkish HIV/AIDS patients in Istanbul was unsafe sex. In the mid 1990s, IVDU was the highest risk factor for HIV transmission in Indonesia. This shifting of risk factors begins with the increasing prevalence of sex workers since 1995-1996, followed by increasing cases in MSM and housewives. ${ }^{10}$ Until now, patients with HIV highly observed among housewives. $^{4}$
The introduction of safe sex to teenagers should start at early age. Lack of strategies to approach adolescent for sex education can be a risk factor because of lack of knowledge about the risks of early sexual intercourse and condom use. The high numbers of adolescent who run away from home make them easily exposed to alcohol and drugs that will increase the risk of HIV transmission. ${ }^{9}$ The use of alcohol and drugs can increase the desire to perform unsafe sex. ${ }^{9,10}$

Human immunodeficiency virus infection impairs the cellular immune system causing people infected with HIV will show susceptibility to opportunistic infections which is the leading cause of mortality and morbidity. The impairment of the cellular immune system can be monitored by measuring the number of CD4 lymphocytes in the blood. The decline of the CD4 lymphocytes number is a sign of disease progression of HIV/ AIDS. Mucocutaneous manifestations can be increased with the development of HIV and CD4 decline. ${ }^{5}$

Mucocutaneous manifestations in HIV patients can be found as infection, noninfection and tumor. In developed countries, non-infection cases in HIV patients commonly encountered due to the differences in their skin pigmentation, climate, hygiene, genetic, 
environment, demographic and behavioral patterns. In contrast in developing countries such as Indonesia, infection cases in HIV patients commonly encountered. ${ }^{11}$ The different in mucocutaneous manifestations leads to different clinical manifestations and epidemiological patterns. In this study, the infection cases were higher $(71.3 \%)$ than that reported in the previous studies. ${ }^{5,6}$ The main infection cases was a fungal infection $(56.7 \%)$, which is dominated by oral candidiasis. This can be caused by tropical climate in Indonesia with relatively high levels of air humidity make various types of germs, including fungal infections growing easily. ${ }^{12}$

A significant association between CD4 cell counts and a fungal infection ( $p$ $<0.0001)$, viral infection $(\mathrm{p}=0.002)$ and parasitic infection $(\mathrm{p}=0.0017)$ was reported in this study. We reported strong relationships with CD4 cell counts $<200$ cells $/ \mathrm{mm}^{3}$ found in fungal infections with a risk 3.8 times compared with CD4 cell counts $\geq 200$ cells/ $\mathrm{mm}^{3}$. In contrast, the number of CD4 cell counts $\geq 200$ cells $/ \mathrm{mm}^{3}$ increase the risk of parasite infection and virus 5 and 2.5 times, respectively. The HIV patients with high CD4 cell counts still had good immune responses that can good respond to specific pathogens. In contrast, the HIV patients with a low CD4 cell counts had lower immune response which cause opportunistic infections such as viral and parasitic infections hardly recognized. ${ }^{13}$ Unlike viral and parasitic infections, fungal infections were more common in low CD4 cell counts. The HIV infection can alter the course of fungal diseases, so the lower the CD4 cell counts leading to higher fungal infections. ${ }^{14}$

Sexually transmitted infections (STIs) may increase the risk of HIV transmission. The sexual behavior like not using condoms, multiple partners increases the risk of STIs. Inflammation due to STIS can cause skin and mucosa not intact, so can facilitate the entry of HIV virus. ${ }^{15}$ In this study STIs cases found only $26 \%$ of all cases of HIV infection. This can happen because some the HIV patient in the Dr Sardjito General Hospital might perform safe sex like a condom use, do not change partners, abstinence, or their STIs cases have been cared in primary care. The highest STIs cases found in this study was condyloma acuminata cases (46.3\%). Condyloma acuminata is the most common manifestation of STIs found in HIV patients. The difficulty to eliminate HPV virus with various therapeutic modalities make condyloma acuminata has high resistance. ${ }^{16}$

Patients with HIV/AIDS have high risk to malignancy, such as Kaposi's sarcoma, nonHodgkin lymphoma and cervix carcinoma. This three malignancy is often called AIDSdefining condition, i.e. when it is found one of this three malignancies, can show the course of HIV infection has reached the stage of AIDS. The relationship between HIV infection with a particular type of malignancy is still unexplained, possibly related to a decrease in immune system. ${ }^{17}$ Kaposi's sarcoma was first found on Jewish descent, young men in Africa and organ transplant recipients. Currently Kaposi sarcoma is the most common malignancy in homosexual HIV patients and related to human herpes virus (HHV). ${ }^{17,18}$ In this study only found one case of Kaposi sarcoma among 205 HIV patients. This can be caused by other malignancies in patients at Dr. Sardjito General Hospital not performed HIV screening.

\section{CONCLUSION}

Alteration in CD4 cell counts affects the opportunistic infections occurence in HIV patients. Lower CD4 cell counts ( $<200$ cells/ $\mathrm{mm}^{3}$ ) increases the risk of fungal infection as much as 3.8 times. Higher CD4 cell counts 
$\left(>200\right.$ cells $\left./ \mathrm{mm}^{3}\right)$ increases the risk of viral infection by about 2.5 times and parasitic infections as much as 5 times.

\section{ACKNOWLEDGEMENTS}

We would like to thank our colleagues from Department of Dermatology and Venereology, Faculty of Medicine, Universitas Gadjah Mada/Dr. Sardjito General Hospital, Yogyakarta for their valuable assistances during the study conducted.

\section{REFERENCES}

1. World Health Organization. Global health observatory data: HIV/AIDS. [serial online]. 2016 [cited 2016 March 28]. Available from: http://www.who.int/gho/hiv/en/

2. The Joint United Nations Programme on HIV/ AIDS (UNAIDS). Global AIDS Update 2017 [serial online]. 2017 [cited 2017 August 28]. Available from : http://aidsinfo.unaids.org/

3. Ministry of Health, Republic of Indonesia. Statistik kasus HIV/AIDS di Indonesia. [serial onoline]. 2016. [cited 2016 March 23]. Available from: http://spiritia.or.id/Stats/ StatCurr.pdf

4. Ministry of Health, Republic of Indonesia. Situasi dan analisis HIV AIDS. [serial online]. 2014 [cited 2016 March 23]. Available from:hhttp://www.depkes.go.id/ resources/ download/pusdatin/infodatin/Infodatin $\% 20$ AIDS.pdf

5. Aydin ÖA, Karaosmanoğlu KH, Korkusuz R, Özeren M, Özcan N. Mucocutaneous manifestation and the relationship to CD4 lymphocyte counts among Turkish HIV/ AIDS patients in Istanbul, Turkey. Turk J Med Sci 2015; 45(1):89-92. http://dx.doi.org/10.3906/sag-1308-3

6. Singh H, Singh P, Tiwari P, Dey V, Dulhani N, Singh A. Dermatological manifestation in HIV-Infested patients at a tertiary care hospital in a tribal (Bastar) region of Chhattisgarh, India. Indian J Dermatol 2009; 54(4):338-41. http://dx.doi.org/10.4103/0019-5154.57609

7. Oninla OA. Mucocutaneous manifestations of HIV and the correlation with WHO clinical staging in a tertiary hospital in Nigeria. AIDS Res Treat 2014;2014:360970. http://dx.doi.org/10.1155/2014/360970.

8. Vijaya Kumari A, Penchalaiah K, Sreenivasulu Naik R. Mucocutaneous manifestations in HIV patients. Int J Sci Res 2016; 5:240-2.

9. Avert. Men who have sex withmen (MSM) and HIV AIDS. [serial online]. 2016 [cited 2016 March 25]. Available from : http:// www.avert.org/professionals/hiv-socialissues/key-affected-populations/men-sexmen\#footnote9_8wpg3qu.

10. Mboi N, Smith KH. Current status of HIV/ AIDS in Indonesia and prospect for its spread. In: Yamamoto T, Itoh S. editor. 'Indonesia,' fighting a rising tide: the response to AIDS in East Asia. Tokyo: Japan center for international exchange, 2006: 96118.

11. Amerson EH, Maurer TA. Dermatologic manifestation of HIV in Africa. Top HIV Med 2010; 18(1):16-22.

12. Febriani. Pola penyakit saraf pada penderita HIV AIDS di RSUP Dr. Kariadi Semarang. [internet]. 2010. [cited 2016 March 28]. Available from : http://eprints.undip. ac.id/23633/1/Nurul_F.pdf.

13. Sharma SK, Soneja M. HIV and immune reconstitution inflammatory syndrome (IRIS). Indian J Med Res 2010; 134(6):866-77. http://dx.doi.org/10.4103/0971-5916.92632

14. da Silva BC, Paula CR, Auler ME, Ruiz Lda S, Dos Santos JI, Yoshioka MC, et al. Dermatophytosis and immunovirological status of HIV infected and AIDS patients from Sao Paulo city Brazil. Mycoses 2014; 57(6):371-6. http://dx.doi.org/10.1111/myc.12169

15. Cohen MS. Sexually transmitted disease enhance HIV transmission: no longer a 
Satiti Retno Pudjiati et al., Correlation between CD4 cell counts with mucocutaneous manifestations: study of HIV patients in Dr. Sardjito General Hospital, Yogyakarta

hypothesis. Lancet 1998; 351(suppl III):5-7.

http://dx.doi.org/10.1016/S01406736(98)90002-2

16. Singrodia S, Panchal M, Solanki RB, Rawal RC. Resistant condyloma acuminata in HIV positive patient treated with cryotherapy once a week along with alternate day application of topical imiquimod 5\% cream. Indian J Sex Transm Dis 2008; 29(1):49-50.

http://dx.doi.org/10.4103/0253-7184.42721

17. Robert H. Lurie Comprehensive CancerCenter of Northwestern. Types of Cancer: AIDS/HIV related malignancies. [serial online]. 2016 [cited 2016 February 20th]. Available from: http://cancer.northwestern.edu/cancertypes/ cancer_type. cfm?category $=1 \#$

18. Robert H. Lurie Comprehensive Cancer Center of Northwestern. HIV and AIDS related cancer:introduction. [serial online]. 2016 [cited March 23th]. Available from: http://cancer.northwestern.edu/cancertypes/ cancer_type.cfm?category $=1 \#$ 